Article

\title{
Bostrychines A-F, Six Novel Mycosporine-Like Amino-Acids and a Novel Betaine from the Red Alga Bostrychia scorpioides
}

\author{
Maria Orfanoudaki ${ }^{1}$, Anja Hartmann ${ }^{1, *}$, Helena Miladinovic ${ }^{1}$, Hieu Nguyen $\operatorname{Ngoc}^{1}{ }^{1}$, \\ Ulf Karsten $^{2}$ D and Markus Ganzera ${ }^{1}$ (D) \\ 1 Institute of Pharmacy, Pharmacognosy, University of Innsbruck, Innrain 80-82, 6020 Innsbruck, Austria; \\ Maria.Orfanoudaki@uibk.ac.at (M.O.); Helena.Miladinovic@student.uibk.ac.at (H.M.); \\ hieu.nguyen-ngoc@student.uibk.ac.at (H.N.N.); markus.ganzera@uibk.ac.at (M.G.) \\ 2 Institute of Biological Sciences, Applied Ecology \& Phycology, University of Rostock, Albert-Einstein-Str. 3, \\ 18059 Rostock, Germany; ulf.karsten@uni-rostock.de \\ * Correspondence: Anja.Hartmann@uibk.ac.at; Tel.: +43-512-507-58430
}

Received: 3 May 2019; Accepted: 11 June 2019; Published: 14 June 2019

check for updates

\begin{abstract}
Various red algae have repeatedly been reported to produce a variety of UV-absorbing mycosporine-like amino acids (MAAs), compounds that are well-known as natural sun-screens, as well as a plethora of betaines, metabolites which contribute to the osmotic balance under salt stress. Among other Rhodophyta, Bostrychia scorpioides, which is thriving as epiphyte on salt marsh plants in Europe and hence experiences extreme environmental conditions such as desiccation, UV-stress and osmotic stress, has barely been investigated for its secondary metabolites. In the present study, seven mycosporine like-amino acids and two betaines were isolated from Bostrychia scorpioides using various chromatographic techniques. Their structures were confirmed by Nuclear Magnetic Resonance (NMR) spectroscopy and High Resolution Mass Spectrometry (HRMS). Six MAAs and one betaine were chemically characterized as new natural products.
\end{abstract}

Keywords: Bostrychia scorpioides; MAAs; Bostrychines A-F; betaines

\section{Introduction}

The genus Bostrychia (Ceramiales, Rhodomelaceae) consists of approximately 40 species which are taxonomically accepted at present and they are widely distributed in tropical and warm temperate environments [1]. However, cryptic species are known to occur in several species complexes of Bostrychia, such as B. tenella, B. radicans, B. moritziana, B. simpliciuscula, B. calliptera and B. intricata $[2,3]$. Although the genus Bostrychia has recently received attention regarding its phylogeny and evolution, only a few studies have addressed their chemical composition, including reports on the occurrence of fatty acids, amino acids, carbohydrates, polysaccharides, betaines, phenolics, and mycosporine-like amino acids (MAAs) [4-9]. Regarding the latter, Bostrychia species have been reported to produce varying quantities of the UV-absorbing compounds mycosporine-glycine, shinorine, porphyra-334, palythine, asterina-330 and palythinol $[9,10]$, however there are no detailed structural reports on the betaines.

The marine red alga Bostrychia scorpioides (Hudson) Montagne (Ceramiales, Rhodomelaceae) is the only species of this genus which abundantly grows on European coasts. Its habitat is above the high water tide mark on lower stems of saltmarsh flowering plants such as Atriplex (Halimione) portulacoides, Spartina anglica, Pulcinella maritima or Sarcocornia perennis [11-13]. B. scorpioides is wetted by sea water only during extreme high tides, and it is therefore able to survive several weeks exposed to air [12]. Consequently, Karsten et al. (1989) characterised B. scorpioides as a "terrestrial" red alga, due to its 
ability to tolerate incomplete turgor pressure regulation, which seems to be decisive for its uppermost intertidal distribution.

Growing under these conditions the alga experiences both severe osmotic and desiccation stresses. Therefore, it is interesting to understand its responses and osmotic acclimation during salinity stress. One of the protective mechanisms is the regulation of internal concentrations of the main ions $\mathrm{K}^{+}, \mathrm{Na}^{+}$, and $\mathrm{Cl}^{-}[12,14]$, and the concentration of organic compounds which are important osmolytes such as polyols, amino acids or betaines [12,15]. Like other species of the genus Bostrychia, B. scorpioides has evolved a $\mathrm{CO}_{2}$ photoassimilation process which is different from that of other red algae, by producing the isomeric hexitols, D-sorbitol, and D-dulcitol $[16,17]$ instead of typical heterosides floridoside or digeneaside. Furthermore, Bostrychia scorpioides is reported to adjust its pigment content and photosynthetic performance, and is able to reduce its internal nitrogen and phosphor turnover at tidal levels allowing the species to cope with fluctuating environmental conditions [18].

Mycosporine-like amino acids form a compound class of water-soluble metabolites of low molecular weight with UV absorption maxima ranging from 268 to $360 \mathrm{~nm}$ [19-21]. They are distributed in a wide range of marine organisms [20,22], especially those inhabiting ecosystems that are highly insolated such as shallow marine environments, where MAAs are used as a natural UV-sunscreen against solar radiation [19]. The UV-absorbing properties of MAAs are well-established in the literature $[19,21]$. Numerous studies of MAAs from various organisms exposed to a high intensity of photosynthetically active radiation (PAR) and harmful ultraviolet radiation (UVR) suggest that MAA act as a protective sunscreen in marine organisms [21-23]. In addition, in recent years various MAAs are also considered as efficient antioxidants and heat dissipaters, and hence may also contribute to the desiccation tolerance and osmotic balance under salinity stress [20,22,24-28].

Betaines on the other hand, are zwitterionic quaternary amines with a widespread distribution in bacteria, fungi, animals, and plants [29]. In marine algae they occur in amounts of less than $1 \%$ (dry weight), and their yields are generally higher in Rhodophyta and Chlorophyta compared to brown algae [30]. The most common betaines in algae are glycine-betaine, $\gamma$-aminobutyric acid-betaine, proline-betaine, and 3-dimethylsulphoniopropionate. Their role as osmoprotectants is well-established since they are known to contribute to survival and cellular adaptation under osmotic pressure and they can have taxonomic significance at the generic level [30-32].

The focus of the present study was to investigate the chemical composition of B. scorpioides targeting stress metabolites like MAAs and betaines since its saltmarsh habitat is unique and quite different from those of other Bostrychia species and other red algae. Thus, the extreme environment may affect the biosynthesis and biochemistry of this species, and lead to the production of yet unexplored molecules. To date there is only one study from Karsten et al. (2000), regarding the presence of MAAs in B. scorpioides. These authors reported that a field sample of B. scorpioides from the Netherlands contained an unknown MAA together with shinorine, palythine, and asterina- 330 whereas a field sample from France contained mycosporine-glycine, shinorine, palythine, and asterina-330 [10].

\section{Results}

The methanolic extract of B. scorpioides was fractionated on a silica gel column, followed by several separation steps using flash chromatography on reversed phase material (C-18). After final purification on a semi-preparative High-Performance-Liquid-Chromatography (HPLC), nine compounds (Figure 1) were isolated.

\subsection{Compound 1}

Characteristic Nuclear Magnetic Resonance (NMR) shifts indicated the presence of a cyclohexeniminetype MAA scaffold. The side chain was identified as glutamine based on a COSY correlation of $\mathrm{H}-9 / \mathrm{H}-11 / \mathrm{H}-12$ and two carbonyl groups at $\delta_{\mathrm{C}} 179.1$ and 181.1, and by comparison with literature values [33]. Its position was confirmed by long-range correlations visible in the HMBC spectrum (H-9 at $\delta_{\mathrm{H}} 4.22$ to $\mathrm{C}-3$ at $\left.\delta_{\mathrm{C}} 163.9\right)$, and relevant connectivities are indicated by arrows in Figure 2 . 
Specifically, a methine at $\delta_{\mathrm{H}} 4.22(\mathrm{H}-9)$ showed a correlation in the COSY spectrum with the protons of the methylene at $\delta_{\mathrm{H}} 2.18$ and $\delta_{\mathrm{H}} 2.26(\mathrm{H}-11)$, and an $\mathrm{HMBC}$ correlation with the carbonyl group at $\delta_{\mathrm{C}} 179.1(\mathrm{C}-10)$. Furthermore, the protons of the methylene at $\mathrm{C}-12\left(\delta_{\mathrm{H}} 2.45\right)$ showed a correlation in the COSY spectrum with the protons of the methylene at position $11\left(\delta_{\mathrm{H}} 2.18\right.$ and 2.26) and an HMBC correlation with the carbonyl group at $\delta_{\mathrm{C}} 181.1$ (C-13). Glutamine has already been found individually in another MAA, mycosporine-glutamine. The latter was discovered by Bernillon et al., in 1983 [34]. Advanced Marfey's method confirmed the presence of L-glutamic acid as final reaction product (Figure S8) indicating L-configuration as absolute configuration of the glutamine at the MAA. Glutamine is reported to be instable during the incubation with hydrochloric acid at $100{ }^{\circ} \mathrm{C}$ resulting in the degradation products pyroglutamic acid and glutamic acid [35]. Since pyroglutamic acid is a secondary amine, it will not react with Marfey's reagent in contrast to glutamic acid which is a primary amine. As for the chiral carbon 5, it is depicted in all MAAs of the present study with the generally accepted configuration [36-40] although further studies have to prove the absolute configuration of this stereochemical center. Compound $\mathbf{1}$ was finally identified as a new MAA, Palythine-Glutamine or ((S)-5-hydroxy-5-(hydroxymethyl)-3-imino-2-methoxycyclohex-1-en-1-yl)-L-glutamine, with the molecular formula: $\mathrm{C}_{13} \mathrm{H}_{21} \mathrm{~N}_{3} \mathrm{O}_{6}$ (high resolution mass spectrometry data: $[\mathrm{M}+\mathrm{H}]^{+}=316.1472$, $[2 \mathrm{M}+\mathrm{Na}]^{+}=653.2617$, Figure S7), it was given the trivial name bostrychine-A.

However, the ${ }^{1} \mathrm{H}-\mathrm{NMR}$ spectrum of compound $\mathbf{1}$ showed three additional signals corresponding to a known betaine, choline as an impurity (compound 9, ratio 3:1 as established by the integration in the ${ }^{1} \mathrm{H}-\mathrm{NMR}$ spectrum). The occurrence of choline was determined by the presence of a methylene at $\delta_{\mathrm{H}} 3.52\left(\delta_{\mathrm{C}} 70.2\right)$ which is visible in a COSY correlation with the protons of a second methylene at $\delta_{\mathrm{H}} 4.06$ and an $\mathrm{HMBC}$ correlation with three methyl groups at $\delta_{\mathrm{C}} 58.5\left(\delta_{\mathrm{H}} 3.20,9 \mathrm{H}\right)$. Choline was additionally confirmed by LC-MS analysis since the respective chromatogram showed two main peaks (Figure S9). The first peak is corresponding to choline (chemical formula: $\mathrm{C}_{5} \mathrm{H}_{13} \mathrm{NO}$ ), with MS values of $m / z 104.3[\mathrm{M}+\mathrm{H}]^{+}$and $m / z 207.3[2 \mathrm{M}+\mathrm{H}]^{+}$. The second peak is corresponding to compound 1 with an $m / z$ value of $316.2[\mathrm{M}+\mathrm{H}]^{+}$.

\subsection{Compound 2}

Characteristic NMR shifts and 2D-NMR data (Tables 1 and 2) of compound 2 indicated the same substructure as compound 1 . However, the ${ }^{1} \mathrm{H}-\mathrm{NMR}$ spectrum showed three extra signals, two doublets at $\delta_{\mathrm{H}} 4.07\left(\mathrm{~J} 4.7 \mathrm{~Hz}, \mathrm{H}-1^{\prime}\right)$ and $\delta_{\mathrm{H}} 1.25\left(\mathrm{~J}=6.6 \mathrm{~Hz}, \mathrm{H}-4^{\prime}\right)$ and a multiplet at $\delta_{\mathrm{H}} 4.31\left(\mathrm{H}-3^{\prime}\right)$. The protons of the methine at $\delta_{\mathrm{H}} 4.07\left(\mathrm{H}-1^{\prime}\right)$ showed correlation in the HMBC spectrum with the carbon at $\delta_{\mathrm{C}} 178.1\left(\mathrm{C}-2^{\prime}\right)$ revealing the presence of a threonine moiety. The HMBC correlation of the same proton $\left(\mathrm{H}-1^{\prime}\right)$ to carbon $\mathrm{C}-1$ at $\delta_{\mathrm{C}} 162.4$ indicated that threonine is attached to position $\mathrm{C}-1$. The presence of L-glutamic acid and L-threonine as constituents was again confirmed by LC-MS using the advanced Marfey's method (Figure S16). As the NMR data of all substructures were in good agreement with literature values, compound $\mathbf{2}$ was finally identified as a new MAA, mycosporine-threonine-glutamine or ((Bostrychine)-3-(((1S,2R)-1-carboxy-2-hydroxypropyl)imino)-5-hydroxy-5-(hydroxymethyl)-2methoxycyclohex-1-en-1-yl)-L-glutamine with molecular formula: $\mathrm{C}_{17} \mathrm{H}_{27} \mathrm{~N}_{3} \mathrm{O}_{9}$ (high resolution MS data: $[\mathrm{M}+\mathrm{H}]^{+}=418.1739$, Figure $\left.\mathrm{S15}\right)$, for which we propose the trivial name bostrychine-B.

\subsection{Compound 3}

Analyses of the 2D-NMR spectra of compound 3 revealed a high similarity to compound 1. However, carbons 12 and 13 were slightly deshielded (Tables 1 and 2) indicating the presence of a glutamic acid moiety instead of glutamine. This was supported by high resolution MS data corresponding to $[\mathrm{M}+\mathrm{H}]^{+}=317.1310$ (Figure S22), from which the molecular formula $\mathrm{C}_{13} \mathrm{H}_{21} \mathrm{~N}_{3} \mathrm{O}_{6}$ was established. Glutamic acid has been reported twice in the literature as a substituent at the cyclohexenimine MAAs i.e., mycosporine-glycine-glutamic acid and mycosporine-glutamic acid [41]. NMR data of both substructures were in good agreement with literature values and advanced Marfey's method showed that the absolute configuration of glutamic acid in the MAA was L 
(Figure S23). Thus, compound 3, named bostrychine-C, was identified as palythine-glutamic acid or ((S)-5-hydroxy-5-(hydroxymethyl)-3-imino-2-methoxycyclohex-1-en-1-yl)-L-glutamic acid, a new MAA with the molecular formula: $\mathrm{C}_{13} \mathrm{H}_{20} \mathrm{~N}_{2} \mathrm{O}_{7}$.

\subsection{Compound 4}

2D-NMR spectra of compound 4 were highly similar to those of compound 2 revealing a cyclohexenimine scaffold and a threonine moiety. Additionally, high resolution MS data were recorded, corresponding to $[\mathrm{M}+\mathrm{H}]^{+}=419.1172$ and $[\mathrm{M}-\mathrm{H}]^{-}=417.1469$ (Figure S29) from which the molecular formula $\mathrm{C}_{17} \mathrm{H}_{26} \mathrm{~N}_{2} \mathrm{O}_{10}$ could be established. However, carbons 12 and 13 of compound 4 differed slightly from those of compound 2, and characteristic NMR shifts and 2D-NMR spectra (Tables 1 and 2) confirmed the presence of a glutamic acid moiety attached to carbon atom $3\left(\delta_{C} 163.4\right)$ of the cyclohexenimine skeleton. The absolute configuration of both amino acids was confirmed to be $L$ (Figure S30). Thus, compound 4, bostrychine-D with molecular formula: $\mathrm{C}_{17} \mathrm{H}_{26} \mathrm{~N}_{2} \mathrm{O}_{10}$, was identified as mycosporine-threonine-glutamic acid or $((S, E)-3-(((1 S, 2 R)-1$-carboxy-2-hydroxypropyl)imino)-5-hydroxy-5-(hydroxymethyl)-2-methoxycyclohex -1-en-1-yl)-L-glutamic acid.

\subsection{Compound 5}

Comparison of the 2D-NMR spectra of compound 5 to that of compound 3 indicated a high degree of similarity. However, in the ${ }^{1} \mathrm{H}-\mathrm{NMR}$ spectrum four additional signals were noticed, two doublets at $\delta_{\mathrm{H}} 3.44$ and $3.51(\mathrm{H}-9)$, a multiplet at $\delta_{\mathrm{H}} 4.02(\mathrm{H}-10)$, and a doublet at $\delta_{\mathrm{H}} 1.22(\mathrm{H}-11)$. Further analyses of the 2D-NMR spectra (Tables 1 and 2) of compound 5 indicated the presence of a threamine (1-amino-2-propanol) moiety. Threamine has been reported in the literature as a substitution of the cyclohexenimine skeleton already, for example in the MAA aplysiapalythine A [42].

The HMBC correlation of protons $\mathrm{H}-9$ of the threamine moiety $\left(\delta_{\mathrm{H}} 3.44\right.$ and 3.51$)$ to carbon $\mathrm{C}-3$ at $\delta_{\mathrm{C}} 164.5$ and of proton $\mathrm{H}-1^{\prime}$ of the glutamic acid moiety $\left(\delta_{\mathrm{H}} 4.43\right)$ to carbon C-1 at $1 \delta_{\mathrm{C}}$ 61.8 indicated at which position, threamine and glutamic acid are attached to the cyclohexenimine scaffold. Their absolute configuration L-glutamic acid $R$-threamine was confirmed as described before (Figure S38 and S39). Since the NMR data of all substructures were in good agreement to literature values, compound 5 was finally identified as a new MAA, mycosporine-threamine-glutamic acid or (S)-2-(((S,E)-5-hydroxy-5-(hydroxymethyl)-3-(((R)-2-hydroxypropyl)amino)-2-methoxycyclohex-2-en -1-ylidene)amino)pentanedioic acid. The compound was named bostrychine-E, and it has the molecular formula $\mathrm{C}_{16} \mathrm{H}_{26} \mathrm{~N}_{2} \mathrm{O}_{8}$ (high resolution MS data: $[\mathrm{M}+\mathrm{H}]^{+}=375.1737$, Figure S37).

\subsection{Compound 6}

Based on the characteristic NMR shifts (Tables 1 and 2) of compound $\mathbf{6}$ a cyclohexenimine-scaffold and the presence of the amino acids threonine and $\beta$-alanine could be concluded. The HMBC correlation of proton $\mathrm{H}-9$ of the $\beta$-alanine moiety $\left(\delta_{\mathrm{H}} 3.76\right)$ to carbon $\mathrm{C}-3$ at $\delta_{\mathrm{C}} 164.2$ indicated that $\beta$-alanine is attached to carbon atom 3 , whereas an $\mathrm{HMBC}$ correlation of proton $\mathrm{H}-\mathrm{1}^{\prime}$ of the threonine moiety $\left(\delta_{\mathrm{H}} 4.35\right)$ to carbon $\mathrm{C}-1$ at $\delta_{\mathrm{C}} 161.8$ confirmed that threonine is attached at this position to the cyclohexenimine scaffold. By LC-MS the absolute configuration of glutamic acid could be determined to be L (Figure S47). As the NMR data of all substructures were in good agreement to literature values, compound 6 was finally identified as a new MAA, mycosporine-threonine- $\beta$-alanine or (2S,3R)-2-(((S,E)-3-((2-carboxyethyl)amino)-5-hydroxy-5-(hydroxymethyl)-2-methoxycyclohex-2-en1-ylidene)amino)-3-hydroxybutanoic acid. Its molecular formula is $\mathrm{C}_{15} \mathrm{H}_{24} \mathrm{~N}_{2} \mathrm{O}_{8}$ (high resolution MS data: $[\mathrm{M}+\mathrm{H}]^{+}=361.1586$, Figure S46) and we suggest the name bostrychine-F for this novel natural product. 


\subsection{Compound 7}

Characteristic NMR shift values (Section 4.4.7) of compound 7 indicated an MAA with cyclohexenone-scaffold and the presence of glutamic acid. As NMR data were in good agreement with literature values [40], compound 7 was identified as the known MAA mycosporine-glutamic acid. Its molecular formula is $\mathrm{C}_{13} \mathrm{H}_{19} \mathrm{NO}_{8}$ (ESIMS $m / z 318[\mathrm{M}+\mathrm{H}]^{+}$; ESIMS m/z $316[\mathrm{M}-\mathrm{H}]^{-}$).

\subsection{Compound 8}

The ${ }^{1} \mathrm{H}-\mathrm{NMR}$ spectrum of compound 8 revealed the presence of five methylene groups, a triplet-type methyl group at $\delta_{\mathrm{H}} 0.90(3 \mathrm{H}, \mathrm{s})$, three methyl groups observed as a singlet at $\delta_{\mathrm{H}}$ $3.18(9 \mathrm{H}, \mathrm{s})$, as well as a methine group at $\delta_{\mathrm{H}} 3.61$. The ${ }^{13} \mathrm{C}$ NMR spectra showed the appearance of two carbonyl groups at $\delta_{\mathrm{C}} 174.8$ and 180.0. The COSY spectrum revealed two coupling networks, including $\mathrm{H}-2 / \mathrm{H}-3 / \mathrm{H}-4 / \mathrm{H}-5 / \mathrm{H}-6$ and $\mathrm{H}-8 / \mathrm{H}-9 / \mathrm{H}-10$. Two substructures were connected through an amide bond by specific chemical shifts of position $6\left(\delta_{\mathrm{H}} 3.21, \delta_{\mathrm{C}} 41.5\right)$ and $8\left(\delta_{\mathrm{H}} 2.21, \delta_{\mathrm{C}} 40.6\right)$, and key HMBC correlations of H-6, 8, 9/C-7 $\left(\delta_{\mathrm{C}}\right.$ 180.0). Furthermore, the HMBC correlations of H-2 $\left(\delta_{\mathrm{H}} 3.61\right)$ and $\mathrm{H}-3\left(\delta_{\mathrm{H}} 1.86\right.$ and 1.95$)$ to $\mathrm{C}-1\left(\delta_{\mathrm{C}} 174.8\right)$, as well as those of the methyl groups at $\delta_{\mathrm{H}} 3.18(\mathrm{H}-11)$ to $\mathrm{C}-2\left(\delta_{\mathrm{C}} 81.8\right)$ confirmed the presence of a betaine group. Compound 8 was assigned the molecular formula $\mathrm{C}_{13} \mathrm{H}_{26} \mathrm{~N}_{2} \mathrm{O}_{3}$ as established by positive ions $[\mathrm{M}+\mathrm{Na}]^{+}$at $m / z 281.1809$ and $[2 \mathrm{M}+\mathrm{Na}]^{+}$at $\mathrm{m} / z 539.3740$ (Figure S53). Collectively, compound 8 was finally identified as (S)-6-butyramido-2-(trimethylammonio)hexanoate or butyryl-lysine-betaine, a new natural product.

Apart from the isolated compounds, six additional MAAs were present in the methanolic extract of B. scorpioides. Due to the minor concentration of compounds i, ii in the extract (Figure 3), their isolation was not feasible. Compounds iii-vi on the other hand were instable, and despite the higher concentration of some of them in the extract, their isolation and structure elucidation was also impossible. Their absorption maxima and molecular masses are summarized in Table S1.<smiles>COC1=C(N[C@@H](CCC(N)=O)C(=O)O)C[C@](O)(CO)CC1=N</smiles>

1<smiles>COC1=C(NC(=O)C(=O)O)C[C@@](O)(CO)CC1=N[C@@H](CCC(=O)O)C(=O)O</smiles>

5<smiles>COC1=C(N[C@H](CCC(N)=O)C(=O)O)C[C@@](O)(CO)C/C1=N\[C@@H](C(=O)O)C(C)O</smiles>

2<smiles>COC1=C(NCCC(=O)O)C[C@@](O)(CO)CC1=N[C@@H](C(=O)O)C(C)O</smiles>
6<smiles>COC1=C(N[C@H](CCC(=O)O)C(=O)O)C[C@](O)(CO)CC1N</smiles>

3

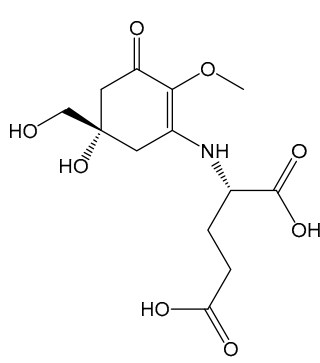

7<smiles>COC1=C(N[C@@H](CCC(=O)O)C(=O)O)C[C@@](O)(CO)CC1=N[C@@H](C(=O)O)[C@@H](C)O</smiles>

4

Figure 1. The chemical structures of compounds 1-9 as elucidated by Nuclear Magnetic Resonance (NMR) spectroscopy. 
Table 1. ${ }^{1} \mathrm{H}$ NMR data of compounds 1-6.

\begin{tabular}{|c|c|c|c|c|c|c|}
\hline \multirow{2}{*}{ Position } & 1 (400 MHz) & 2 (600 MHz) & 3 (600 MHz) & $4(600 \mathrm{MHz})$ & 5 (600 MHz) & $6(600 \mathrm{MHz})$ \\
\hline & $\delta H(J$ in $\mathrm{Hz})$ & $\delta H(J$ in $\mathrm{Hz})$ & $\delta H(J$ in $\mathrm{Hz})$ & $\delta H(J$ in $\mathrm{Hz})$ & $\delta H(J$ in $\mathrm{Hz})$ & $\delta H(J$ in $\mathrm{Hz})$ \\
\hline \multirow[b]{2}{*}{4} & $2.76, \mathrm{~d}(17.8)$ & $2.77, \mathrm{~d}(17.4)$ & $2.76, \mathrm{~d}(17.4)$ & $2.80, \mathrm{~d}(18.0)$ & \multirow{2}{*}{$2.90, \mathrm{~s}$} & \multirow{2}{*}{$2.95, \mathrm{~s}$} \\
\hline & $2.83, \mathrm{~d}(17.8)$ & 2.81, d (17.4) & $2.81, \mathrm{~d}(17.4)$ & $2.83, \mathrm{~d}(18.0)$ & & \\
\hline \multirow{2}{*}{6} & $2.68, \mathrm{~d}(17.2)$ & $2.75, \mathrm{~d}(17.4)$ & $2.67, \mathrm{~d}(17.4)$ & $2.77, \mathrm{~d}(17.4)$ & $2.81, \mathrm{~d}(18.0)$ & $2.74, \mathrm{~d}(17.4)$ \\
\hline & 2.97, d (17.2) & 2.91, d (17.4) & 2.95, d (17.4) & 2.90, d (17.4) & $2.76, \mathrm{~d}(18.0)$ & $2.88, \mathrm{~d}(17.4)$ \\
\hline 7 & $3.57, \mathrm{~s}$ & $3.57, \mathrm{~s}$ & $3.56, \mathrm{~s}$ & $3.56, \mathrm{~s}$ & $3.58, \mathrm{~s}$ & $3.59, \mathrm{~s}$ \\
\hline 8 & $3.65, \mathrm{~s}$ & $3.70, \mathrm{~s}$ & $3.63, \mathrm{~s}$ & $3.69, \mathrm{~s}$ & $3.61, \mathrm{~s}$ & $3.63, \mathrm{~s}$ \\
\hline 9 & $4.22, \mathrm{dd}(8.0,4.8)$ & $4.23, \mathrm{dd}(7.8 / 4.8)$ & $\begin{array}{l}4.23, \mathrm{dd} \\
(8.4 / 4.8)\end{array}$ & $4.43, \mathrm{dd}(8.4 / 4.8)$ & $\begin{array}{l}3.44, \mathrm{~d}(14.4 / 7.8) \\
3.51, \mathrm{~d}(14.4 / 2.4)\end{array}$ & $3.76, \mathrm{t}(6.0)$ \\
\hline 10 & & & & & $4.02, \mathrm{~m}$ & $2.78, \mathrm{t}(6.0)$ \\
\hline \multirow[b]{2}{*}{11} & $2.18, \mathrm{~m}$ & $2.18, \mathrm{~m}$ & $2.12, \mathrm{~m}$ & $2.20, \mathrm{~m}$ & \multirow{2}{*}{$1.22, \mathrm{~d}(6.0)$} & \\
\hline & $2.26, \mathrm{~m}$ & $2.28, \mathrm{~m}$ & $2.24, \mathrm{~m}$ & $2.34, \mathrm{~m}$ & & \\
\hline 12 & $2.45, \operatorname{td}(7.62 .0)$ & $2.45, \operatorname{td}(7.4 / 2.4)$ & $2.41, \mathrm{~m}$ & $2.57, \operatorname{td}(7.2 / 1.8)$ & & \\
\hline $1^{\prime}$ & & $4.07, \mathrm{~d}(4.8)$ & & $4.27, \mathrm{~d}(4.8)$ & $4.43, \mathrm{dd}(7.8 / 5.4)$ & $4.35, \mathrm{~m}$ \\
\hline $3^{\prime}$ & & $4.31, \mathrm{~m}$ & & $4.39, \mathrm{~m}$ & $\begin{array}{l}2.19, \mathrm{~m} \\
2.34, \mathrm{~m}\end{array}$ & $4.44, \mathrm{~m}$ \\
\hline $4^{\prime}$ & & $1.25, \mathrm{~d}(6.0)$ & & $1.25, \mathrm{~d}(6.6)$ & $2.57,(\mathrm{t}, 7.2)$ & $1.25, \mathrm{~d}(6.6)$ \\
\hline
\end{tabular}

Table $2 .{ }^{13} \mathrm{C}$ NMR data of compounds $\mathbf{1}-\mathbf{6}$ and $\mathbf{8}$.

\begin{tabular}{|c|c|c|c|c|c|c|c|}
\hline \multirow{2}{*}{ Position } & $\begin{array}{c}\text { 1a (400 } \\
\text { MHz) }\end{array}$ & $\begin{array}{l}2(600 \\
\mathrm{MHz})\end{array}$ & $\begin{array}{l}3(600 \\
\text { MHz) }\end{array}$ & $\begin{array}{l}4(600 \\
\mathrm{MHz})\end{array}$ & $\begin{array}{l}5(600 \\
\mathrm{MHz})\end{array}$ & $\begin{array}{l}6(600 \\
\text { MHz) }\end{array}$ & $\begin{array}{l}8(600 \\
\mathrm{MHz})\end{array}$ \\
\hline & $\delta_{\mathrm{C}}$, Type & $\delta_{\mathrm{C}}$, Type & $\delta_{\mathrm{C}}$, Type & $\delta_{\mathrm{C}}$, Type & $\delta_{\mathrm{C}}$, Type & $\delta_{\mathrm{C}}$, Type & $\delta_{\mathrm{C}}$, Type \\
\hline 1 & 163.6, C & $162.4, \mathrm{C}$ & 163.6, C & 163.1, C & $161.8, \mathrm{C}$ & $161.8, \mathrm{C}$ & $174.8, \mathrm{CO}$ \\
\hline 2 & 127.7, C & $128.8, \mathrm{C}$ & $127.8, \mathrm{C}$ & 129.2, C & $128.8, \mathrm{C}$ & $128.8, \mathrm{C}$ & $81.8, \mathrm{CH}$ \\
\hline 3 & $163.9, \mathrm{C}$ & $162.8, \mathrm{C}$ & 164.4, C & $163.4, \mathrm{C}$ & $164.5, \mathrm{C}$ & $164.2, \mathrm{C}$ & $28.7, \mathrm{CH}_{2}$ \\
\hline 4 & $36.4, \mathrm{CH}_{2}$ & $36.2, \mathrm{CH}_{2}$ & $36.5, \mathrm{CH}_{2}$ & $36.1, \mathrm{CH}_{2}$ & $36.1, \mathrm{CH}_{2}$ & $35.8, \mathrm{CH}_{2}$ & $25.5, \mathrm{CH}_{2}$ \\
\hline 5 & $74.2, \mathrm{C}$ & 74.0, C & $74.1, \mathrm{C}$ & $74.0, \mathrm{C}$ & $74.0, \mathrm{C}$ & $74.0, \mathrm{C}$ & $30.9, \mathrm{CH}_{2}$ \\
\hline 6 & $38.5, \mathrm{CH}_{2}$ & $36.0, \mathrm{CH}_{2}$ & $38.5, \mathrm{CH}_{2}$ & $36.2, \mathrm{CH}_{2}$ & $36.0, \mathrm{CH}_{2}$ & $36.1, \mathrm{CH}_{2}$ & $41.6, \mathrm{CH}_{2}$ \\
\hline 7 & $70.2, \mathrm{CH}_{2}$ & $70.3, \mathrm{CH}_{2}$ & $70.3, \mathrm{CH}_{2}$ & $70.4, \mathrm{CH}_{2}$ & $70.4, \mathrm{CH}_{2}$ & $70.4, \mathrm{CH}_{2}$ & $180.0, \mathrm{CO}$ \\
\hline 8 & $61.9, \mathrm{CH}_{3}$ & $62.4, \mathrm{CH}_{3}$ & $62.0, \mathrm{CH}_{3}$ & $62.5, \mathrm{CH}_{3}$ & $62.2, \mathrm{CH}_{3}$ & $62.3, \mathrm{CH}_{3}$ & $40.6, \mathrm{CH}_{2}$ \\
\hline 9 & $61.4, \mathrm{CH}$ & $61.5, \mathrm{CH}$ & $61.7, \mathrm{CH}$ & $60.2, \mathrm{CH}$ & $53.1, \mathrm{CH}_{2}$ & $42.3, \mathrm{CH}_{2}$ & 22.0, $\mathrm{CH}_{2}$ \\
\hline 10 & $179.1, \mathrm{CO}$ & $179.3, \mathrm{CO}$ & $179.3, \mathrm{CO}$ & $178.1, \mathrm{CO}$ & $69.5, \mathrm{CH}$ & $36.7, \mathrm{CH}_{2}$ & $15.6, \mathrm{CH}_{3}$ \\
\hline 11 & $30.5, \mathrm{CH}_{2}$ & $30.6, \mathrm{CH}_{2}$ & $30.8, \mathrm{CH}_{2}$ & $29.7, \mathrm{CH}_{2}$ & 22.3, $\mathrm{CH}_{3}$ & $178.2, \mathrm{CO}$ & $54.6, \mathrm{CH}_{3}$ \\
\hline 12 & $34.2, \mathrm{CH}_{2}$ & $34.3, \mathrm{CH}_{2}$ & $35.4, \mathrm{CH}_{2}$ & $33.2, \mathrm{CH}_{2}$ & & & \\
\hline 13 & $181.1, \mathrm{CO}$ & $181.2, \mathrm{CO}$ & $182.6 \mathrm{CO}$ & $180.3, \mathrm{CO}$ & & & \\
\hline $1^{\prime}$ & & $67.4, \mathrm{CH}$ & & $66.3, \mathrm{CH}$ & 59.6, $\mathrm{CH}$ & $65.3, \mathrm{CH}$ & \\
\hline $2^{\prime}$ & & $178.1, \mathrm{CO}$ & & $176.9, \mathrm{CO}$ & $178.0, \mathrm{CO}$ & $176.5, \mathrm{CO}$ & \\
\hline $3^{\prime}$ & & $71.1, \mathrm{CH}$ & & $70.8, \mathrm{CH}$ & 29.7, $\mathrm{CH}_{2}$ & $70.6, \mathrm{CH}$ & \\
\hline $4^{\prime}$ & & $22.3, \mathrm{CH}_{3}$ & & $22.2, \mathrm{CH}_{3}$ & $33.2, \mathrm{CH}_{2}$ & $22.1, \mathrm{CH}_{3}$ & \\
\hline $5^{\prime}$ & & & & & $180.3, \mathrm{CO}$ & & \\
\hline
\end{tabular}




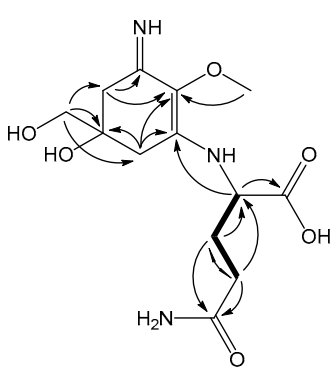

1

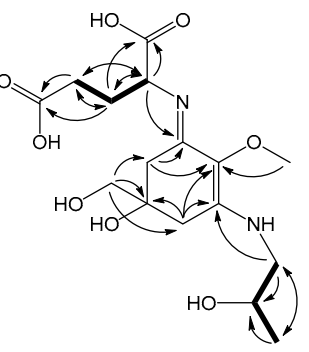

5

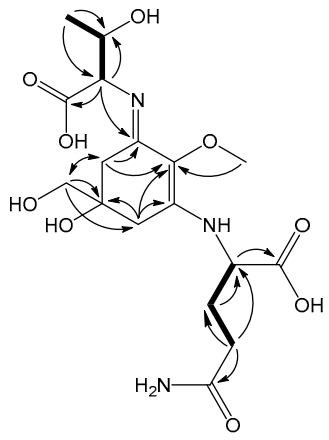

2

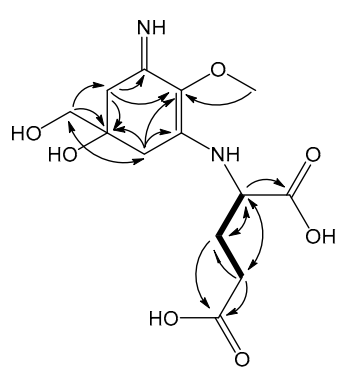

3

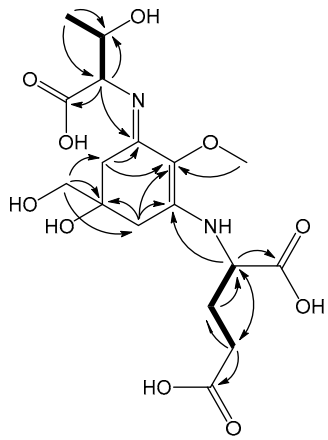

4

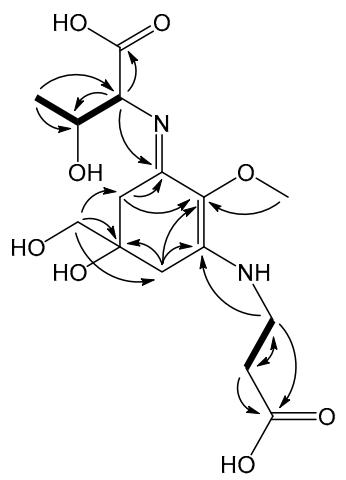

6

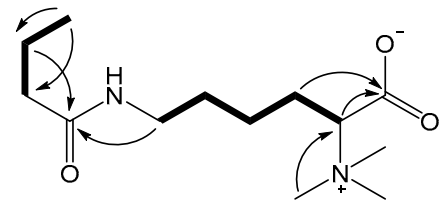

8

COSY

HMBC

Figure 2. Key HMBC $\left({ }^{1} \mathrm{H} \rightarrow{ }^{13} \mathrm{C}\right)$ and ${ }^{1} \mathrm{H}_{-}{ }^{1} \mathrm{H}$ COSY correlations of compounds $\mathbf{1}-\mathbf{6}$ and $\mathbf{8}$.

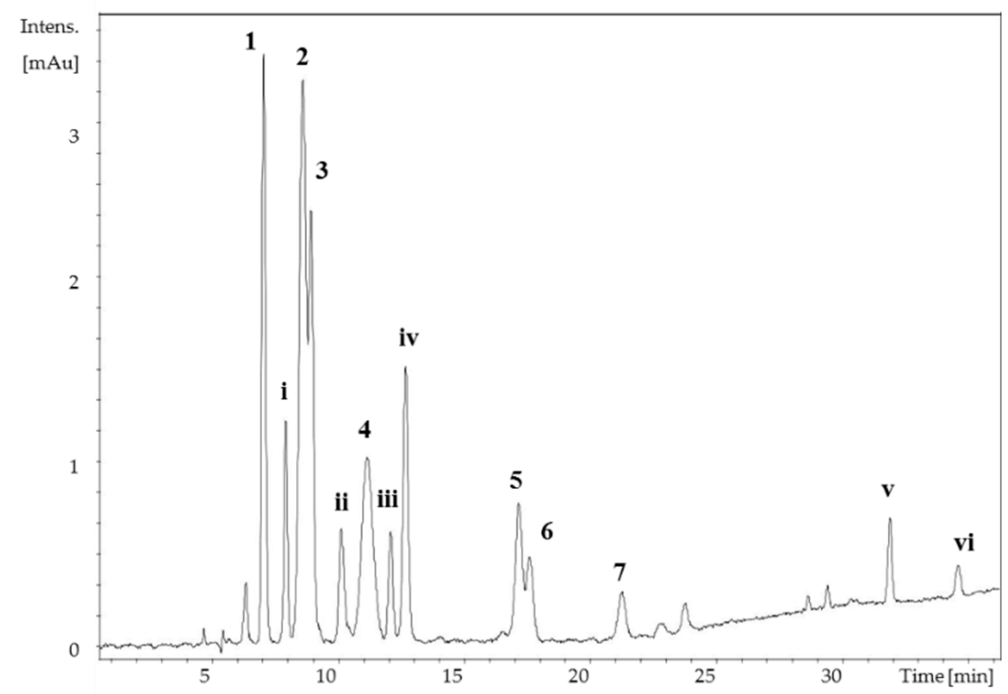

Figure 3. HPLC-UV separation of the Bostrychia scorpioides MeOH extract. Peak assignment is according to Figure 1. 1-7: isolated mycosporine-like amino acids (MAAs), i-vi: unidentified compounds (Table S1), column: YMC-Pack ODS $(250 \times 4.60 \mathrm{~mm}, 5 \mu \mathrm{m})$ mobile phase: $20 \mathrm{mM}$ ammonium formate and $0.6 \%(v / v)$ formic acid in water (A) and methanol (B); gradient: 0-15 min: $2 \% \mathrm{~B}, 23 \mathrm{~min}: 10 \% \mathrm{~B}$, 30 min: $15 \%$ B, 35-40 min: $98 \%$ B, 40.1-50 $\min : 2 \%$ B; $\lambda=310,330$, and $350 \mathrm{~nm}$; flow rate $=0.6 \mathrm{~mL} / \mathrm{min}$; $\mathrm{T}=20^{\circ} \mathrm{C}$. 


\section{Discussion and Conclusions}

The research on mycosporine-like amino acids, molecules well-known for their UV-protective properties, has gained the attention of the scientific community and cosmetic industry during the last decades not only because they can act as sunscreens in marine organisms [21-23] but also as efficient antioxidants and multifunctional secondary metabolites [22].

B. scorpioides was selected for this study because of its unique and extreme natural habitat, as well as due to an interesting MAA pattern, during an initial HPLC screening of the extract. Subsequently, six novel MAAs, mycosporine-glutamic acid and one novel betaine were isolated using a purification protocol which included silica gel chromatography, flash chromatography and semi-preparative HPLC. All novel MAAs had a cyclohexenimine-scaffold with the amino acids, glutamic acid, glutamine and threonine as side chains, while the betaine was a lysine derivative. The MAA pattern of this species is therefore completely different to that of other species from the genus Bostrychia or other red algae which usually contain porphyra-334, shinorine, asterina-330, palythine, aplysiapalythine-A, mycosporine-glycine, aplysiapalythine $\mathrm{B}$, mycosporine-glycine-alanine, mycosporine-methylamine-threonine, palythene and usujirene [43].

Additionally, six further compounds (compounds i-vi) were detected in the extract of B. scorpioides, but because of either low concentration or poor stability, their structure could not be elucidated. However, the absorption maxima and molecular masses of compounds ii and iii would agree with those of mycosporine-glycine-aspartic acid, isolated previously from a brine shrimp [44] and mycosporine-glutamine, isolated from a fungus [35], respectively. The presence of mycosporine-glutamine in this alga would be plausible, given the presence of mycosporine-glutamic acid, palythine- glutamine and mycosporine-threonine-glutamine (compounds 1-3), as well as its instable nature, which is characteristic for cyclohexenone type MAAs. Additionally, compounds v and vi showed absorption maxima in the range of $360 \mathrm{~nm}$, which is unique because only two other MAAs have been reported to exhibit so high absorption maxima (357-360 nm), namely usujirene and palythene. However, due to their high instability the structure of compounds $\mathbf{v}$ and vi could not be elucidated. The absorption maxima and molecular masses of compounds $\mathbf{i}-\mathbf{v i}$ are summarized in Table S1.

The present data is in contrast with the results published by Karsten et al. in 2000 [10], which reported that samples of Bostrychia scorpioides contained an MAA present also in Catenella sp., shinorine, palythine, asterina-330, and mycosporine-glycine. However, compared to our approach this earlier publication was only based on a HPLC method without coupling to an MS detector for a deeper chemical characterization. In addition, it might be possible that samples of Bostrychia from different biogeographical origins produce different MAAs, since we know from other taxa that biogeography is an important factor for shaping chemical profiles in red algae due to variabilities in environmental settings (e.g., solar radiation, day length, temperature, salinity, nutrients etc.) [45].

In the salt marsh habitat $B$. scorpioides is exposed to higher environmental irradiance levels than other Bostrychia species in tropical habitats, where they preferentially grow as epiphytes on the prop roots of mangroves which provide shade by the canopy [10,46,47]. The biochemical capability to synthesize and accumulate MAAs is a highly efficient photoprotective mechanism. While many intertidal red algae typically contain three to five different MAAs for photoprotection, the relatively high number of 12 compounds in $B$. scorpioides is rather unusual and might be explained by the rather unique habitat. In our recent study Bostrychia arbuscula exhibited only five MAAs [43]. These compounds act as passive shielding solutes by dissipating the absorbed solar UV radiation energy in the harmless form of heat without generating photochemical reactions [48]. MAAs are chemically characterized by extremely high molar absorptivity for UVA and UVB (molar extinction coefficients between 28.000 and 50.000), and have been reported to be photochemically stable molecules, both of which are prerequisites for their experimentally proven sunscreen function [49].

To date, the role of MAAs for maintaining osmotic homeostasis is not very clear. Many studies report that dilution stress leads to an immediate excretion of MAAs from the cells or that the MAA 
content increases with a rise in salinity [50-52]. On the other hand, the MAA concentrations that are reported, although being significant, are still much lower than those required to balance the salinity stress [27]. Therefore, these substances might act as supplementary osmolytes together with other osmotic solutes like betaines or low molecular weight carbohydrates such as floridoside or polyols $[26,51]$. Taking into consideration that B. scorpioides grows in salt marshes on herbs and scrubs where it is regularly confronted with osmotic stress, it would be interesting to investigate whether the isolated MAAs are linked to increases and decreases in external salinity. On the other hand, the osmoprotective role of betaines in organisms which experience severe osmotic and desiccation stress is well-documented $[30,53]$ and together with low molecular weight carbohydrates they are considered the main metabolites contributing to osmotic regulation. Therefore, it is reasonable to assume such an ecophysiological role of the novel betaine and choline found in B. scorpioides. Together with digeneaside, D-sorbitol, and D-dulcitol this species contains an array of organic osmolytes which contribute to the high salinity tolerance of this red alga and thus explain the ecological success under the extreme and fluctuating environmental conditions in salt marshes.

\section{Materials and Methods}

\subsection{Biological Material}

The algal material was collected at Plouescat, France on 14 June 2018 and was morphologically identified by the author $\mathrm{U}$. Karsten using his taxonomic expert knowledge in conjunction with standard identification keys [1,54]; the alga was air-dried and stored at $22{ }^{\circ} \mathrm{C}$ until further processing. A voucher sample is deposited at the Institute of Pharmacy, Pharmacognosy, University of Innsbruck, Austria.

\subsection{Instrumentation}

NMR experiments were conducted on a Bruker Avance II 600 spectrometer (Karlsruhe, Germany) operating at $600.19\left({ }^{1} \mathrm{H}\right)$ and $150.91 \mathrm{MHz}\left({ }^{13} \mathrm{C}\right)$. The isolated compounds were dissolved in deuterated water from Euriso-Top (Saint Aubin, France) using tetramethylsilane (TMS) as internal standard. High-resolution mass spectra were measured with a micrOTOF-Q II mass spectrometer (Bruker-Daltonics, Bremen, Germany). The experiments were performed in the positive or negative ESI mode with the following parameters: capillary energy, $4500 \mathrm{~V}$ for positive mode and $3500 \mathrm{~V}$ for negative mode; nebulizer gas, $6.4 \mathrm{psi}$; dry gas, $4.0 \mathrm{~L} / \mathrm{min}$ at a temperature of $180^{\circ} \mathrm{C}$; the recorded scan range was 100-600 m/z. Low-resolution mass spectra were measured with an Agilent InfinityLab LC/MSD System comprising of an Agilent HPLC 1260 HPLC, equipped with a binary pump, autosampler, column oven and photodiode array detector Agilent 1260 HPLC (Santa Clara, CA, USA). The experiments were performed in the positive or negative ESI mode with the following parameters: capillary energy, $4000 \mathrm{~V}$; nebulizer gas, $40.0 \mathrm{psi}$; dry gas, $10.0 \mathrm{~L} / \mathrm{min}$ at a temperature of $300^{\circ} \mathrm{C}$; the recorded, scan range was $100-1500 \mathrm{~m} / \mathrm{z}$.

For the purification of compounds, a Reveleris ${ }^{\circledR}$ X2 iES flash chromatography system (Büchi, Flawil, Switzerland) and a semi-preparative Dionex UltiMate 3000 HPLC (Thermo, Waltham, MA, USA), comprising a P580 pump, an ASI 100 auto-mated sample injector, an UVD 170 U detector and a fraction collector, were used. Analytical HPLC experiments were performed on a Shimadzu LC-20AD XR system. Optical rotations were measured using a Jasco P-2000 digital polarimeter (Jasco Austria, Biolab GmbH and Co., Wien, Austria).

\subsection{Chemicals and Reagents}

All solvents required for extraction and isolation were purchased from VWR International (Vienna, Austria), and ethyl acetate was distilled before use. Solvents for analytical experiments had at least pro analysis (p.a.) quality and were obtained from Merck (Darmstadt, Germany). Deuterated solvents were supplied by Euriso-Top (Saint-Aubin Cedex, France). Ultrapure water was produced by a Sartorius arium ${ }^{\circledR} 611$ UV (Göttingen, Germany) purification system. Silica gel 40-63 $\mu \mathrm{m}$ and pre-packed 
cartridges for flash chromatography were purchased from Merck (Darmstadt, Germany) and Büchi (Flawil, Switzerland), respectively.

\subsection{Extraction and Isolation}

The plant material (990 g) was crushed to powder in a grinding mill and extracted thrice in an ultrasonic bath (Bandelin Sonorex $35 \mathrm{KHz}$, Berlin, Germany) for $15 \mathrm{~min}$ using dichloromethane (10 L in total) which afforded $3.7 \mathrm{~g}$ of dichloromethane extract (yield $0.4 \%$ ). For MAA extraction the remaining dry plant material was first extracted using pure methanol (approximately $20 \mathrm{~L}$ ) under the same conditions (73 $\mathrm{g}$ of methanolic extract, yield 7.4\%), followed by a threefold extraction with methanol/water $=1 / 1(v / v)(4 \mathrm{~L}$ of solvent) which afforded $58 \mathrm{~g}$ of water extract (yield $5.9 \%)$. HPLC analysis of the extracts indicated that the methanol extract contained MAAs, therefore it was selected for further fractionation.

The methanolic extract $(73 \mathrm{~g})$ was fractionated on a silica gel column $(80 \times 5 \mathrm{~cm}, 800 \mathrm{~g}$ of silica gel) using gradient elution (EtOAc to methanol), resulting in 21 fractions. Fractions 15, 16, and 17 were individually fractionated with flash chromatography, using a C-18 $40 \mathrm{~g}$ cartridge from Büchi. Elution was carried out by the following water (A) and $\mathrm{MeOH}(\mathrm{B})$ gradient: 0-15 min: 0\% B, $25 \mathrm{~min}$ : $100 \% \mathrm{~B}, 25-40 \mathrm{~min}: 100 \% \mathrm{~B}$. The flow rate was $10 \mathrm{~mL} \mathrm{~min}^{-1}$ and UV detection performed at 254,310 , and $350 \mathrm{~nm}$.

Flash chromatography of fraction 15 (3.5 g) resulted in six sub-fractions. Sub-fraction $15 \mathrm{~b}(2.3 \mathrm{~g})$ was subjected to semi-preparative HPLC using a Synergi $4 \mathrm{u}$ Polar-RP column $(250 \times 10 \mathrm{~mm}, 4 \mu \mathrm{m}$; Phenomenex, Torrance, CA, USA). The mobile phase comprised of $0.1 \%(v / v)$ trifluoroacetic acid in water (A) and $0.25 \%(v / v)$ formic acid in methanol (B) and the following gradient was used: 0 min: $2 \% \mathrm{~B}$, 15 min: $2 \%$ B, $20.1 \mathrm{~min}: 50 \%$ B, $25 \mathrm{~min}: 98 \%$ B, $30 \mathrm{~min}: 98 \%$ B, 30.1-40 min: $2 \%$ B. The separation was monitored at $330 \mathrm{~nm}$, column temperature and flow rate were set to $21^{\circ} \mathrm{C}$ and $1.3 \mathrm{~mL} / \mathrm{min}$, respectively. This resulted in the isolation of compounds $2(1.5 \mathrm{mg})$ and $3(0.96 \mathrm{mg})$. Sub-fraction 15e $(170 \mathrm{mg})$ was subjected to semi-preparative HPLC on an Aqua C18 column ( $250 \times 10 \mathrm{~mm}, 5 \mu \mathrm{m}$; Phenomenex), using a mobile phase comprising of $0.25 \%(v / v)$ formic acid in water (A) and methanol (B); the applied gradient was: $0 \mathrm{~min}: 2 \% \mathrm{~B}, 5 \mathrm{~min}: 5 \% \mathrm{~B}, 25 \mathrm{~min}: 10 \% \mathrm{~B}, 25.1-30 \mathrm{~min}: 2 \% \mathrm{~B}$. The separation was monitored at $330 \mathrm{~nm}$, column temperature and flow rate were set to $21^{\circ} \mathrm{C}$ and $1.3 \mathrm{~mL} / \mathrm{min}$, respectively. This step resulted in the isolation of compounds $\mathbf{1}$ and $\mathbf{9}$ as a mixture $(6.9 \mathrm{mg})$.

Flash chromatography of fraction 16 (2.6 g) resulted in seven subfractions. Sub-fraction $16 \mathrm{~b}(1 \mathrm{~g})$ was subjected to semi-preparative HPLC using a Synergi $4 \mathrm{u}$ Polar-RP column $(250 \times 10 \mathrm{~mm}, 4 \mu \mathrm{m}$; Phenomenex, Torrance, CA, USA). The mobile phase comprised of $0.1 \%(v / v)$ trifluoroacetic acid in water (A) and $0.25 \%(v / v)$ formic acid in methanol (B) and the following gradient was used: 0 min: $2 \%$ B, 5 min: $10 \%$ B, 25 min: $20 \%$ B, 30 min: $20 \%$ B, 35 min: $40 \%$ B, 40 min: $98 \%$ B, 40.1 min: $2 \%$ B, $55 \mathrm{~min}: 2 \% \mathrm{~B}$. The separation was monitored at $355 \mathrm{~nm}$, column temperature and flow rate were set to $21^{\circ} \mathrm{C}$ and $1.3 \mathrm{~mL} / \mathrm{min}$, respectively. The goal of this isolation step was the purification of compounds $\mathbf{v}$ and vi which were unstable and therefore finally could not be identified. However, this purification step led to the isolation of compound $\mathbf{8}(3.1 \mathrm{mg})$ whose presence was confirmed by LC-MS analysis. Sub-fraction 16c (71 mg) was subjected to semi-preparative HPLC using the same column and solvent system (UV detection wavelength: $330 \mathrm{~nm}$, column temperature: $21^{\circ} \mathrm{C}$ and flow rate: $1.3 \mathrm{~mL} / \mathrm{min}$ ). The following gradient was used: $0 \mathrm{~min}: 2 \% \mathrm{~B}, 55 \mathrm{~min}: 2 \% \mathrm{~B}$, resulting in the isolation of compounds 5 $(3.9 \mathrm{mg})$ and $6(6.6 \mathrm{mg})$.

Flash chromatography of fraction $17(2.7 \mathrm{~g})$ resulted in six subfractions. Sub-fraction $17 \mathrm{~b}(2.3 \mathrm{~g})$ was subjected to semi-preparative HPLC using a Synergi $4 \mathrm{u}$ Polar-RP column $(250 \times 10 \mathrm{~mm}, 4 \mu \mathrm{m}$; Phenomenex, Torrance, CA, USA). The mobile phase comprised of $0.25 \%(v / v)$ formic acid in water (A) and methanol (B) and the following gradient was used: 0 min: $2 \%$ B, 5 min: 5\% B, 25 min: $10 \%$ B, 25.1-35 min: $2 \%$ B (UV detection wavelength: $330 \mathrm{~nm}$, column temperature: $21^{\circ} \mathrm{C}$ and flow rate: $1.3 \mathrm{~mL} / \mathrm{min})$. This resulted in the isolation of compounds $4(5.9 \mathrm{mg})$ and $7(0.8 \mathrm{mg})$. 


\subsubsection{Bostrychine-A (1)}

White amorphous powder; UV $\lambda \max =322 \mathrm{~nm} ;{ }^{1} \mathrm{H}$ and ${ }^{13} \mathrm{C}$ NMR data $\left(400 / 100 \mathrm{MHz} ; \mathrm{D}_{2} \mathrm{O}\right)$, Tables 1 and 2; ESIMS $m / z 316[\mathrm{M}+\mathrm{H}]^{+}$; HRESIMS $m / z$ 316.1472 $[\mathrm{M}+\mathrm{H}]^{+}\left(\right.$calcd. for $\mathrm{C}_{13} \mathrm{H}_{22} \mathrm{~N}_{3} \mathrm{O}_{6}$, 316.1509).

\subsubsection{Bostrychine-B (2)}

Pale yellow amorphous powder; $[\alpha]^{21} \mathrm{D}=-29.1$ (c $1, \mathrm{H}_{2} \mathrm{O}$ ); UV $\lambda \max =335 \mathrm{~nm} ; \varepsilon=36,155$ $\mathrm{M}^{-1} \cdot \mathrm{cm}^{-1} ;{ }^{1} \mathrm{H}$ and ${ }^{13} \mathrm{C}$ NMR data $\left(600 / 150 \mathrm{MHz} ; \mathrm{D}_{2} \mathrm{O}\right)$, Tables 1 and 2; ESIMS $m / z 418[\mathrm{M}+\mathrm{H}]^{+}$; HRESIMS $m / z 418.1739[\mathrm{M}+\mathrm{H}]^{+}$(calcd. for $\left.\mathrm{C}_{17} \mathrm{H}_{28} \mathrm{~N}_{3} \mathrm{O}_{9}, 418.1825\right)$.

\subsubsection{Bostrychine-C (3)}

White amorphous powder; $[\alpha]^{21} \mathrm{D}=-33.3\left(\mathrm{c} 1, \mathrm{H}_{2} \mathrm{O}\right) ; \mathrm{UV} \lambda \max =322 \mathrm{~nm} ; \varepsilon=22,351 \mathrm{M}^{-1} \cdot \mathrm{cm}^{-1}$; ${ }^{1} \mathrm{H}$ and ${ }^{13} \mathrm{C}$ NMR data $\left(600 / 150 \mathrm{MHz} ; \mathrm{D}_{2} \mathrm{O}\right)$, Tables 1 and 2; ESIMS $m / z 317[\mathrm{M}+\mathrm{H}]^{+} ;$HRESIMS $m / z$ $317.1310[\mathrm{M}+\mathrm{H}]^{+}$(calcd. for $\mathrm{C}_{13} \mathrm{H}_{21} \mathrm{~N}_{2} \mathrm{O}_{7}, 317.1348$ ).

\subsubsection{Bostrychine-D (4)}

Pale yellow amorphous powder; $[\alpha]^{21}{ }_{\mathrm{D}}=-1.9$ (c $\left.0.1, \mathrm{H}_{2} \mathrm{O}\right)$; UV $\lambda \max =337 \mathrm{~nm} ; \varepsilon=31,956$ $\mathrm{M}^{-1} \cdot \mathrm{cm}^{-1} ;{ }^{1} \mathrm{H}$ and ${ }^{13} \mathrm{C}$ NMR data $\left(600 / 150 \mathrm{MHz} ; \mathrm{D}_{2} \mathrm{O}\right)$, Tables 1 and 2; ESIMS $m / z 419[\mathrm{M}+\mathrm{H}]^{+}$; HRESIMS $m / z$ 419.1172 $[\mathrm{M}+\mathrm{H}]^{+}$(calcd. for $\mathrm{C}_{17} \mathrm{H}_{25} \mathrm{~N}_{2} \mathrm{O}_{10}, 419.1666$ ); and $m / z 417.1469\left[\mathrm{M}-\mathrm{H}^{-}\right.$ (calcd. for $\mathrm{C}_{17} \mathrm{H}_{25} \mathrm{~N}_{2} \mathrm{O}_{10}, 417.1509$ ).

\subsubsection{Bostrychine-E (5)}

Pale yellow amorphous powder; $[\alpha]^{21} \mathrm{D}=-2.2\left(\right.$ c $\left.0.1, \mathrm{H}_{2} \mathrm{O}\right)$; UV $\lambda \max =333 \mathrm{~nm} ; \varepsilon=21,618$ $\mathrm{M}^{-1} \cdot \mathrm{cm}^{-1} ;{ }^{1} \mathrm{H}$ and ${ }^{13} \mathrm{C}$ NMR data $\left(600 / 150 \mathrm{MHz} ; \mathrm{D}_{2} \mathrm{O}\right)$, Tables 1 and 2; ESIMS $m / z 375[\mathrm{M}+\mathrm{H}]^{+}$; HRESIMS $m / z$ 375.1737 [M + H] $]^{+}$(calcd. for $\mathrm{C}_{16} \mathrm{H}_{27} \mathrm{~N}_{2} \mathrm{O}_{8}, 375.1767$ ).

\subsubsection{Bostrychine-F (6)}

Pale yellow amorphous powder; $[\alpha]^{21}{ }_{\mathrm{D}}=-2.4\left(\mathrm{c} 0.1, \mathrm{H}_{2} \mathrm{O}\right)$; UV $\lambda \max =332 \mathrm{~nm} ; \varepsilon=44,994$ $\mathrm{M}^{-1} \cdot \mathrm{cm}^{-1} ;{ }^{1} \mathrm{H}$ and ${ }^{13} \mathrm{C}$ NMR data $\left(600 / 150 \mathrm{MHz} ; \mathrm{D}_{2} \mathrm{O}\right)$, Tables 1 and 2; ESIMS $m / z 361[\mathrm{M}+\mathrm{H}]^{+}$; HRESIMS $m / z 361.1586[\mathrm{M}+\mathrm{H}]^{+}$(calcd. for $\mathrm{C}_{15} \mathrm{H}_{25} \mathrm{~N}_{2} \mathrm{O}_{8}, 361.1611$ ).

\subsubsection{Mycosporine-Glutamic Acid (7)}

White amorphous powder; UV $\lambda \max =310 \mathrm{~nm} ;{ }^{1} \mathrm{H}$ NMR data $\left(600 \mathrm{MHz} ; \mathrm{D}_{2} \mathrm{O}\right), \delta_{\mathrm{H}} 4.12(1 \mathrm{H}, \mathrm{m}$, H-9); 3.59 (3H, s, H-8); 3.52 (2H, s, H-7); 2.75 (1H, d, J = 17.3, Hz H-6); 2.69 (1H, d, J = 17.3 Hz, H-6); $2.67(1 \mathrm{H}, \mathrm{d}, J=17.1 \mathrm{~Hz}, \mathrm{H}-4) ; 2.39(1 \mathrm{H}, \mathrm{d}, J=17.1 \mathrm{~Hz}, \mathrm{H}-4) ; 2.49(2 \mathrm{H}, \mathrm{t}, J=7.4 \mathrm{~Hz}, \mathrm{H}-12) ; 2.20(1 \mathrm{H}, \mathrm{m}$, $\mathrm{H}-11) ; 2.10(1 \mathrm{H}, \mathrm{m}, \mathrm{H}-11)$, ESIMS $m / z 318[\mathrm{M}+\mathrm{H}]^{+}$; ESIMS $m / z 316\left[\mathrm{M}-\mathrm{H}^{-}\right.$.

\subsubsection{Butyryl-lysine-betaine (8)}

Pale yellow amorphous powder; $[\alpha]^{21} \mathrm{D}=+5.1\left(\mathrm{c} 0.1, \mathrm{H}_{2} \mathrm{O}\right) ;{ }^{1} \mathrm{H}$ NMR data $\left(600 \mathrm{MHz} ; \mathrm{D}_{2} \mathrm{O}\right)$, $\delta_{\mathrm{H}} 3.61(1 \mathrm{H}, \mathrm{dd}, J=11.8 / 3.4, \mathrm{H}-2) ; 3.22(2 \mathrm{H}, \mathrm{m}, \mathrm{H}-6) ; 3.18(3 \mathrm{H}, \mathrm{s}, \mathrm{H}-11) ; 2.21(2 \mathrm{H}, \mathrm{t}, J=7.4, \mathrm{H}-8)$; $1.95(1 \mathrm{H}, \mathrm{m}, \mathrm{H}-3) ; 1.90$ (3H, t, J = 7.4, H-10); 1.86 (1H, m, H-3); 1.60 (2H, m, H-5); 1.60 (2H, m, H-9); $1.37(2 \mathrm{H}, \mathrm{m}, \mathrm{H}-4) ;{ }^{13} \mathrm{C}$ NMR data $\left(150 \mathrm{MHz} ; \mathrm{D}_{2} \mathrm{O}\right)$, Table 2; ESIMS $\mathrm{m} / \mathrm{z} 258[\mathrm{M}+\mathrm{H}]^{+}$; HRESIMS $\mathrm{m} / \mathrm{z}$ $281.1181[\mathrm{M}+\mathrm{Na}]^{+}$(calcd. for $\mathrm{C}_{13} \mathrm{H}_{26} \mathrm{~N}_{2} \mathrm{O}_{3} \mathrm{Na}, 281.1841$ ), and $\mathrm{m} / z 539.3740$ [2M + Na] ${ }^{+}$(calcd. for $\mathrm{C}_{26} \mathrm{H}_{52} \mathrm{~N}_{4} \mathrm{O}_{6} \mathrm{Na}$, 539.3784). 


\subsubsection{Choline (9)}

White amorphous powder; ${ }^{1} \mathrm{H}$ NMR data $\left(400 \mathrm{MHz} ; \mathrm{D}_{2} \mathrm{O}\right), \delta_{\mathrm{H}} 4.06(2 \mathrm{H}, \mathrm{m}, \mathrm{H}-1) ; 3.52(2 \mathrm{H}, \mathrm{m}$, $\mathrm{H}-2) ; 3.20(9 \mathrm{H}, \mathrm{s}, \mathrm{H}-3) ;{ }^{13} \mathrm{C}$ NMR data $\left(100 \mathrm{MHz} ; \mathrm{D}_{2} \mathrm{O}\right), \delta_{\mathrm{C}} 70.2$ (C-2); 58.5 (C-3); 56.8 (C-1), ESIMS m/z $104.3[\mathrm{M}+\mathrm{H}]^{+}$and at $m / z 207.3[2 \mathrm{M}+\mathrm{H}]^{+}$.

4.5. Determination of the Absolute Configurations of Amino Acids in MAAs by the Advanced Marfey's Method Using LC-MS

The general procedure was adapted from a previously published protocol [55]. Approximately $0.1 \mathrm{mg}$ of each MAA was stirred with $\mathrm{HCl} 37 \%(250 \mu \mathrm{L})$ at $90^{\circ} \mathrm{C}$ for $120 \mathrm{~min}$. The hydrolysates were evaporated to dryness and then resuspended in $\mathrm{H}_{2} \mathrm{O}(100 \mu \mathrm{L})$.

Each amino acid $(200 \mu \mathrm{g})$ or hydrolysate (ca. $100 \mu \mathrm{g})$ was dissolved in $1 \mathrm{M} \mathrm{NaHCO} 3(200 \mu \mathrm{L})$ and $1 \% \mathrm{D}$ - or L-1-fluoro-2,4-dinitrophenyl-5-L-leucinamide (FDLA) derivatization reagent in acetone $(25 \mu \mathrm{L})$ was added. The reaction vials were incubated and stirred for $30 \mathrm{~min}$ at $50^{\circ} \mathrm{C}$. The reactions were then quenched with $2 \mathrm{~N} \mathrm{HCl}(100 \mu \mathrm{L})$. $\mathrm{MeOH}(800 \mu \mathrm{L})$ was added to prepare LC-MS samples. The reaction products were analyzed by HPLC-MS, using a Luna $5 \mu \mathrm{C}-8$ column $(150 \times 4.6 \mathrm{~mm}, 5 \mu \mathrm{m}$; Phenomenex, Torrance, $\mathrm{CA}$, USA). $\mathrm{H}_{2} \mathrm{O}$ containing $0.1 \%$ formic acid (A) and acetonitrile containing $0.1 \%$ formic acid (B) were used as eluents applying the following gradient: $0 \mathrm{~min}: 5 \% \mathrm{~B}, 1 \mathrm{~min}: 5 \% \mathrm{~B}, 20 \mathrm{~min}: 20 \% \mathrm{~B}$, 40 min: $60 \%$ B, 45 min: $95 \%$ B, $45.1 \mathrm{~min}: 5 \%$ B and $55 \mathrm{~min}: 5 \% \mathrm{~B}$. The DAD detector was set to 210 , $254,280,320,330,350$, and $400 \mathrm{~nm}$, the flow rate, injection volume, and column temperature were adjusted to $0.9 \mathrm{~mL} \mathrm{~min}^{-1}, 20 \mu \mathrm{L}$, and $40{ }^{\circ} \mathrm{C}$, respectively. MS spectra were recorded in positive-ESI mode (capillary voltage $4.5 \mathrm{kV}$ ), with a drying gas temperature of $300^{\circ} \mathrm{C}$, the nebulizer gas (nitrogen) set to $25 \mathrm{psi}$, and a nebulizer flow (nitrogen) of $12.0 \mathrm{~L} \mathrm{~min}^{-1}$. The scanned mass range was set between $m / z 50$ and 600 (Figures S8, S16, S23, S30, S38, S39 and S47).

Supplementary Materials: The following are available online at http://www.mdpi.com/1660-3397/17/6/356/s1, absorption maxima and molecular mass of unidentified MAAs in the methanolic extract of B. scorpioides, HRMS spectra, 1D and 2D NMR spectra of all the new compounds 1-6 and $\mathbf{8}$ as well as chromatograms for Marfey's products of $1-6$.

Author Contributions: Investigation, M.O., H.M., and H.N.N.; resources, U.K.; writing—original draft preparation, M.O.; writing—review and editing and supervision, U.K., A.H., and M.G.

Funding: This research was funded by the Austrian Science Fund (FWF), project No. P296710.

Acknowledgments: The authors gratefully thank Svenja Heesch (Station biologique de Roscoff), Vivien Hotter (Institute of Biological Sciences, Applied Ecology \& Phycology, University of Rostock), Stefanie Hofer (Institute of Pharmacy, Pharmacognosy, University of Innsbruck) and the employees of Station biologique de Roscoff, France for their assistance during the collection of the plant material. Open Access Funding by the Austrian Science Fund (FWF).

Conflicts of Interest: The authors declare no conflict of interest.

\section{References}

1. AlgaeBase. Available online: http://www.algaebase.org/search/genus/detail/?genus_id=32785\&-session= abv4:AC1F05FF0ef232A2D0G1828F52DA (accessed on 26 February 2019).

2. Zuccarello, G.C.; West, J.A. Multiple cryptic species: Molecular diversity and reproductive isolation in the Bostrychia radicans/B. moritziana complex (Rhodomelaceae, Rhodophyta) with focus on North American isolates. J. Phycol. 2003, 39, 948-959. [CrossRef]

3. Muangmai, N.; Ammon, U.; Zuccarello, G. Cryptic species in sympatry: Nonrandom small-scale distribution patterns in Bostrychia intricata (Ceramiales, Rhodophyta). Phycologia 2016, 55, 424-430. [CrossRef]

4. De Oliveira, A.L.L.; da Silva, D.B.; Turatti, I.C.C.; Yokoya, N.S.; Debonsi, H.M. Volatile constituents of Brazilian Bostrychia species (Rhodomelaceae) from mangrove and rocky shore. Biochem. Syst. Ecol. 2009, 37, 761-765. [CrossRef]

5. Karsten, U.; Koch, S.; West, J.A.; Kirst, G.O. The intertidal red alga Bostrychia simpliciuscula Harvey ex J. Agardh from a mangrove swamp in Singapore: Acclimation to light and salinity. Aquat. Bot. 1994, 48, 313-323. [CrossRef] 
6. Martins, C.D.L.; Ramlov, F.; Nocchi Carneiro, N.P.; Gestinari, L.M.; Dos Santos, B.F.; Bento, L.M.; Lhullier, C.; Gouvea, L.; Bastos, E.; Horta, P.A.; et al. Antioxidant properties and total phenolic contents of some tropical seaweeds of the Brazilian coast. J. Appl. Phycol. 2013, 25, 1179-1187. [CrossRef]

7. Felício, R.D.; Debonsi, H.M.; Yokoya, N.S. 4-(Hidroximetil)-Benzenossulfonato de potássio: Metabólito inédito isolado da alga marinha Bostrychia tenella (Rhodomelaceae, ceramiales). Quím. Nova 2008, 31, 837-839. [CrossRef]

8. $\quad$ Oliveira, A.L.L.D.; Silva, D.B.D.; Lopes, N.P.; Debonsi, H.M.; Yokoya, N.S. Chemical constituents from red algae Bostrychia radicans (Rhodomelaceae): New amides and phenolic compounds. Quím. Nova 2012, 35, 2186-2188. [CrossRef]

9. Karsten, U.; Sawall, T.; Wiencke, C. A survey of the distribution of UV-absorbing substances in tropical macroalgae. Phycol. Res. 2006, 46, 271-279.

10. Karsten, U.; Sawall, T.; West, J.; Wiencke, C. Ultraviolet sunscreen compounds in epiphytic red algae from mangroves. Hydrobiologia 2000, 432, 159-171. [CrossRef]

11. Kremer, B.P. 14C-Assimilate pattern and kinetics of photosynthetic 14CO2-assimilation of the marine red alga Bostrychia scorpioides. Planta 1976, 129, 63-67. [CrossRef]

12. Karsten, U.; Kirst, G.O. Incomplete turgor pressure regulation in the "terrestial" red alga, Bostrychia scorpioides (Huds.) Mont. Plant Sci. 1989, 61, 29-36. [CrossRef]

13. Huiskes, A.; Blom, C.W.P.M.; Rozema, J. Vegetation between land and sea: Structure and processes. In Plant Sciences, 3th ed.; Huiskes, A., Blom, C.W.P.M., Rozema, J., Eds.; Springer: Dordrecht, The Netherlands, 1987; pp. 70-71.

14. Kirst, G.O. Osmotische Adaptation bei Algen. Naturwissenschaften 1985, 72, 125-132. [CrossRef]

15. Reed, R.H.; Davison, I.R.; Chudek, J.A.; Foster, R. The osmotic role of mannitol in the Phaeophyta: An appraisal. Phycologia 1985, 24, 35-47. [CrossRef]

16. Kremer, B.P. Distribution of alditols in the genus Bostrychia. Bioche. Syst. Ecol. 1976, 4, 139-141. [CrossRef]

17. Karsten, U.; King, R.J.; Kirst, G.O. The distribution of D-sorbitol and D-dulcitol in the red algal genera Bostrychia and Stictosiphonia (Rhodomelaceae, Rhodophyta)—a re-evaluation. Br. Phycol. J. 1990, 25, 363-366. [CrossRef]

18. Sánchez de Pedro, R. Ecophysiological study of the intertidal zonation of the estuarine rhodophytes Bostrychia scorpioides (Hudson) Montagne ex Kützing and Catenella caespitosa (Withering) L. M. Irvine. Doctoral Thesis, University of Malaga, Malaga, Spain, 21 December 2016.

19. Chrapusta, E.; Kaminski, A.; Duchnik, K.; Bober, B.; Adamski, M.; Bialczyk, J. Mycosporine-like amino acids: potential health and beauty ingredients. Mar. Drugs 2017, 15, 326. [CrossRef]

20. Wada, N.; Sakamoto, T.; Matsugo, S. Mycosporine-like amino acids and their derivatives as natural antioxidants. Antioxidants 2015, 4, 603-646. [CrossRef]

21. Bhatia, S.; Garg, A.; Sharma, K.; Kumar, S.; Sharma, A.; Purohit, A.P. Mycosporine and mycosporine-like amino acids: A paramount tool against ultra violet irradiation. Pharmacogn. Rev. 2011, 5, 138-146. [CrossRef]

22. Oren, A.; Gunde-Cimerman, N. Mycosporines and mycosporine-like amino acids: UV protectants or multipurpose secondary metabolites? FEMS Microbiol. Lett. 2007, 269, 1-10. [CrossRef]

23. Lawrence, K.; Long, P.; Young, A. Mycosporine-Like Amino Acids for Skin Photoprotection. Curr. Med. Chem. 2018, 25, 5512-5527. [CrossRef]

24. Gacesa, R.; Lawrence, K.P.; Georgakopoulos, N.D.; Yabe, K.; Dunlap, W.C.; Barlow, D.J.; Wells, G.; Young, A.R.; Long, P.F. The mycosporine-like amino acids porphyra-334 and shinorine are antioxidants and direct antagonists of Keap1-Nrf2 binding. Biochimie 2018, 154, 35-44. [CrossRef] [PubMed]

25. La Barre, S.; Roullier, C.; Boustie, J. Mycosporine-Like Amino Acids (MAAs) in Biological Photosystems. In Outstanding Marine Molecules: Chemistry, Biology, Analysis, 3th ed.; La Barre, S., Kornprobst, J.M., Eds.; Wiley-Blackwell: Weinheim, Germany, 2014; pp. 333-360.

26. Oren, A. Mycosporine-like amino acids as osmotic solutes in a community of halophilic cyanobacteria. Geomicrobiol. J. 1997, 14, 231-240. [CrossRef]

27. Vale, P. Can mycosporine-like amino acids act as multifunctional compounds in Gymnodinium catenatum (dinophyceae)? Photochem. Photobiol. 2016, 92, 264-275. [CrossRef] [PubMed]

28. De la Coba, F.; Aguilera, J.; Figueroa, F.L.; de Gálvez, M.V.; Herrera, E. Antioxidant activity of mycosporine-like amino acids isolated from three red macroalgae and one marine lichen. J. Appl. Phycol. 2008, 21, 161-169. [CrossRef] 
29. Figueroa-Soto, C.G.; Valenzuela-Soto, E.M. Glycine betaine rather than acting only as an osmolyte also plays a role as regulator in cellular metabolism. Biochimie 2018, 147, 89-97. [CrossRef] [PubMed]

30. Blunden, G.; Smith, B.E.; Irons, M.W.; Yang, M.H.; Roch, O.G.; Patel, A.V. Betaines and tertiary sulphonium compounds from 62 species of marine algae. Bioche. Syst. Ecol. 1992, 20,373-388. [CrossRef]

31. Hosseiniyan Khatibi, S.M.; Zununi Vahed, F.; Sharifi, S.; Ardalan, M.; Mohajel Shoja, M.; Zununi Vahed, S. Osmolytes resist against harsh osmolarity: Something old something new. Biochimie 2019, 158, 156-164. [CrossRef] [PubMed]

32. Stadmiller, S.S.; Pielak, G.J. Glycine betaine reverses osmotic shock induced protein destabilization in living cells. Biophys. J. 2017, 112, 57a. [CrossRef]

33. Tiainen, M.; Maaheimo, H.; Niemitz, M.; Soininen, P.; Laatikainen, R. Spectral analysis of 1H coupled 13C spectra of the amino acids: Adaptive spectral library of amino acid $13 \mathrm{C}$ isotopomers and positional fractional 13C enrichments. Magn. Reson. Chem. 2008, 46, 125-137. [CrossRef] [PubMed]

34. Bernillon, J.; Bouillant, M.L.; Pittet, J.L.; Favre-Bonvin, J.; Arpin, N. Mycosporine glutamine and related mycosporines in the fungus Pyronema omphalodes. Phytochemistry 1984, 23, 1083-1087. [CrossRef]

35. Snowden, M.K.; Baxter, J.H.; Mamula Bergana, M.; Reyzer, I.; Pound, V. Stability of N-acetylglutamine and glutamine in aqueous solution and in a liquid nutritional product by an improved HPLC method. J. Food Sci. 2002, 67, 384-389. [CrossRef]

36. Uemura, D.; Katayama, C.; Wada, A.; Hirata, Y. Crystal and molecular structure of palythene possessing a novel $360 \mathrm{~nm}$ chromophore. Chem. Lett. 1980, 9, 755-756. [CrossRef]

37. Furusaki, A.; Matsumoto, T.; Tsujino, I.; Sekikawa, I. Crystal and molecular structure of palythine trihydrate. Bull. Chem. Soc. Jpn. 1980, 53, 319-323. [CrossRef]

38. Klisch, M.; Richter, P.; Puchta, R.; Häder, D.P.; Bauer, W. The stereostructure of Porphyra-334: An experimental and calculational NMR investigation. Evidence for an efficient 'Proton Sponge'. Helv. Chim. Acta 2007, 90, 488-511. [CrossRef]

39. White, J.D.; Cammack, J.H.; Sakuma, K.; Rewcastle, G.W.; Widener, R.K. Transformations of quinic acid. asymmetric synthesis and absolute configuration of Mycosporin I and Mycosporin-gly. J. Org. Chem. 1995, 60, 3600-3611. [CrossRef]

40. White, J.D.; Cammack, J.H.; Sakuma, K. The synthesis and absolute configuration of mycosporins. A novel application of the Staudinger reaction. J. Am. Chem. Soc. 1989, 111, 8970-8972. [CrossRef]

41. Bandaranayake, W.M.; Bemis, J.E.; Bourne, D.J. Ultraviolet absorbing pigments from the marine sponge Dysidea herbacea: Isolation and structure of a new mycosporine. Comp. Bioch. Physiol. Part C Pharmacol. Toxicol. Endocrinol. 1996, 115, 281-286. [CrossRef]

42. Kamio, M.; Kicklighter, C.E.; Nguyen, L.; Germann, M.W.; Derby, C.D. Isolation and structural elucidation of novel mycosporine-like amino acids as alarm cues in the defensive ink secretion of the sea hare Aplysia californica. Helv. Chim. Acta 2011, 94, 1012-1018. [CrossRef]

43. Orfanoudaki, M.; Hartmann, A.; Karsten, U.; Ganzera, M. Chemical profiling of mycosporine-like amino acids in twenty-three red algal species. J. Phycol. 2019, 55, 393-403. [CrossRef] [PubMed]

44. Grant, P.; Middleton, C.; Plack, P.; Thomson, R. The isolation of four aminocyclohexenimines (mycosporines) and a structurally related derivative of cyclohexane-1:3-dione (Gadusol) from the brine shrimp, Artemia. Compa. Biochem. Physiol. Part B Biochem. Mol. Biol. 1985, 80, 755-759. [CrossRef]

45. Tartarotti, B.; Sommaruga, R. Seasonal and ontogenetic changes of mycosporine-like amino acids in planktonic organisms from an alpine lake. Limnol Oceanogr. 2006, 51, 1530-1541. [CrossRef] [PubMed]

46. Karsten, U.; West, J. Ecophysiological studies on six species of the mangrove red algal genus Caloglossa. Funct. Plant Biol. 1993, 20, 729-739. [CrossRef]

47. King, R.J.; Puttock, C. Morphology and taxonomy of Caloglossa (Delesseriaceae, Rhodophyta). Aust. Syst. Bot. 1994, 7, 89-94. [CrossRef]

48. Bandaranayake, W.M. Traditional and medicinal use of Mangrove. In Mangroves and Salt Marshes, 1st ed.; Springer Verlag: Berlin, Germany, 1998; pp. 133-148.

49. Karsten, U.; Lembcke, S.; Schumann, R. The effects of ultraviolet radiation on photosynthetic performance, growth and sunscreen compounds in aeroterrestrial biofilm algae isolated from building facades. Planta 2007, 225, 991-1000. [CrossRef] [PubMed]

50. Rath, J.; Mandal, S.; Adhikary, S.P. Ecophysiology of the estuarine cyanobacterium Lyngbya aestuarii to varying salinity in vitro. Acta Physiol. Plant. 2014, 36, 409-419. [CrossRef] 
51. Kogej, T.; Gostincar, C.; Volkmann, M.; Gorbushina, A.A.; Gunde-Cimerman, N. Mycosporines in extremophilic fungi-novel complementary osmolytes? Environ. Chem. 2006, 3, 105-110. [CrossRef]

52. Karsten, U. Effects of salinity and ultraviolet radiation on the concentration of mycosporine-like amino acids in various isolates of the benthic cyanobacterium Microcoleus chthonoplastes. Phycol. Res. 2002, 50, 129-134. [CrossRef]

53. Kageyama, H.; Waditee-Sirisattha, R.; Tanaka, Y.; Takabe, T. Chapter 1 - osmoprotectant and sunscreen molecules from halophilic algae and cyanobacteria. In Algal Green Chemistry; Rastogi, R.P., Madamwar, D., Pandey, A., Eds.; Elsevier: Amsterdam, The Netherlands, 2017; pp. 1-16.

54. Hiscock, S. A Field Key to the British Red Seaweed, 1st ed.; Field Studies Council: Somerset, UK, 1986; pp. 44, 47.

55. Fujii, K.; Ikai, Y.; Oka, H.; Suzuki, M.; Harada, K.I. A nonempirical method using LC/MS for determination of the absolute configuration of constituent amino acids in a peptide: Combination of Marfey's method with mass spectrometry and its practical application. Anal. Chem. 1997, 69, 5146-5151. [CrossRef]

(C) 2019 by the authors. Licensee MDPI, Basel, Switzerland. This article is an open access article distributed under the terms and conditions of the Creative Commons Attribution (CC BY) license (http://creativecommons.org/licenses/by/4.0/). 